\title{
Impact of urban landscape and environmental externalities on spatial differentiation of housing prices in Yangzhou City
}

\author{
WANG Yang ${ }^{1}$, 'ZHAO Lingling ${ }^{1,2}$, SOBKOWIAK Leszek ${ }^{3}$, GUAN Xingliang ${ }^{4}$, \\ WANG Shaojian ${ }^{5}$ \\ 1. Guangzhou Institute of Geography, Guangzhou 510070, China; \\ 2. Institute of Geographic Sciences and Natural Resources Research, CAS, Beijing 100101, China; \\ 3. Adam Mickiewicz University, Institute of Physical Geography and Environmental Planning, 61-680 Poznań, \\ Poland; \\ 4. National Academy for Mayors of China, Beijing 100029, China; \\ 5. School of Geography and Planning, Sun Yat-sen University, Guangzhou 510275, China
}

\begin{abstract}
In this study, housing prices data for residential quarters from the period 2001-2012 were used and Global Differentiation Index (GDI) was established to measure the overall differentiation trend in housing prices in Yangzhou City, eastern China. Then the influence of the natural landscape and environment on prices of global housing market and housing submarkets was evaluated by the hedonic price model. The results are shown as follows. (1) There have been increasing gaps among housing prices since 2001. In this period, the differentiation trend has shown an upward fluctuation, which has been coupled with the annual growth rate of housing prices. (2) The spatial distribution of residential quarters of homogenous prices has changed from clustered in 2001 into dispersed in 2012. (3) Natural landscape and environmental externalities clearly influence spatial differentiation of housing prices. (4) In different housing submarkets, the influence of natural landscape and environmental externalities are varied. Natural landscape characteristics have significant impact on housing prices of ordinary commercial houses and indemnificatory houses, while the impact of environmental characteristics have obvious influence on housing prices of cottages and villas.
\end{abstract}

Keywords: housing prices; spatial differentiation; GDI index; hedonic price method; natural landscape; environment; Yangzhou

\section{Introduction}

Spatial differentiation issues of inner city housing prices are an important part of the urban geography studies. Some scholars apply the spatial approach to analyze and portray the spa-

Received: 2014-02-22 Accepted: 2014-03-18

Foundation: National Natural Science Foundation of China, No.41401164, No.41201128

Author: Wang Yang (1984-), $\mathrm{PhD}$, specialized in urban geography, regional and urban planning.

E-mail: wyxkwy@163.com

"Corresponding author: Zhao Lingling, PhD, E-mail: linglingzhao@foxmail.com 
tial distribution of housing prices in urban areas (Chhetri et al., 2009; Koramaz and Dokmec, 2012; Kuethe, 2012) and prove that there commonly exists spatial differentiation of urban housing prices. Analyzing the phenomena of the spatial variation of the housing prices, many scholars use the hedonic price theory to discuss the factors influencing their spatial variation. These factors commonly include: the age of the building (Stevenson, 2004; Helbich et al., 2013), the building structure (Goodman et al., 2003; Helbich et al., 2013), facilities in the residential area (Tse et al., 2000) and other representative housing estate characteristics. The existence of educational facilities ( $\mathrm{Li}$ and $\mathrm{Fu}, 2010$; Machin, 2011), commercial facilities (Des and Lagana, 1996), natural landscape (Wen et al., 2012; Panduro and Veie, 2013) and natural environment (Jim and Chen, 2007; Yusuf and Resosudarmo, 2009) in the surroundings are the representative characteristics of the neighborhood. The distance from CBD (Shi and Li, 2006; He et al., 2010) and the transportation convenience (Smersh and Smith, 2000; Feng et al., 2011) are the representative characteristics of the housing location. These factors constitute the "implicit price" of the housing estate (Rosen, 1974), which determine the spatial differentiation of its prices.

Among these factors the natural landscape and environmental factors affecting the housing prices draw an increasing attention of scholars (Cavailhès et al., 2009; Maslianskaia-Pautrel and Baumont, 2013). Excellent landscape and environment can significantly enhance the value of residential quarters. Empirical studies have shown that the existing green space (Waltert and Schläpfer, 2010; Panduro and Veie, 2013), park (Shi, 2010), water (Platter and Campbell, 1978), lake (Gillard, 1981; Wen et al., 2012), sea (Benson et al., 1998; Maslianskaia-Pautrel and Baumont, 2013), beach (Hamilton and Morgan, 2010;. Landry and Hindsley, 2011), wetlands (Mahan et al., 2000) and other views are positively correlated with housing prices. At the same time, the chaotic or polluted surrounding environment may reduce the value of residential quarters. For example, air pollution (Yusuf, 2009), noise (Duarte and Tamez, 2009; Chang and Kim, 2012), neighborhood of the power plants (Davis, 2011), landfills (Ham et al., 2013), industrial zones (Maslianskaia-Pautrel and Baumont, 2013), urban villages (Song and Zenou, 2012) and other will to some extent reduce the housing prices of the surrounding area. With improvements of the environment the prices (Gamper-Rabindran and Timmins, 2012) of the surrounding area would increase. This proves that the landscape and environment have significant influence on the urban housing prices. In addition, according to the housing submarkets theory (Straszheim, 1975), based on the research of Bourassa et al. (2003), after the housing market sub-division the hedonic price models are different and the models fit better. Therefore, it is necessary to carry out research on the landscape and environmental effects and differences in housing submarkets, respectively.

Chinese urban housing prices show significant regional external effects and a tendency of spreading from the first-tier cities towards the second- and third-tier cities and regions (Fang and Ding, 2012). The Yangtze River Delta region is no exception (Fang et al., 2013; Hong, 2009). That region, including Yangzhou City is China's housing prices high-value agglomeration area (Wang et al., 2013). The Yangzhou City's housing prices are affected by Shanghai (the first-tier cities) and Nanjing (the second-tier cities), with the linkage effects formed. Factors shaping the housing prices in Yangzhou City have also in common with these cities (Wang et al., 2013). According to China Urban Construction Statistical Year- 
book (2010) the population of Yangzhou City was 7.692 million, ranking 95th among 654 cities in China, which makes Yangzhou belongs to the group of big cities; its built-up area was $78.60 \mathrm{~km}^{2}$, ranking 106th. Its moderate urban population and area make Yangzhou City representative for studies on housing prices development. In addition, Yangzhou City has relatively complete history of evolution, including the development of the New Urban Area and redevelopment of the Old Urban Area, the co-existence of the gentrification and suburbanization processes, as well as significant regional differentiation, which make the city a representative example for studies. Since 2001, with the housing system reform in China in 1998, the Yangzhou downtown residential construction area has increased 2.13 times, spreading from the Old Urban Area towards the New Urban Area and the suburbs and causing rapid rise of housing prices. Therefore, the analysis of the spatial differentiation of Yangzhou City housing prices and also the landscape and natural environment influence on them in that period has an important practical value.

In this paper all types of residential quarters located in the Yangzhou downtown are investigated, with the residential quarters (or residential groups) taken as the basic research units, with the full coverage data in 2011 and 2012, and the continuous sample data from 2001 to 2010 as the basic data sources used to investigate the Yangzhou City residential prices spatial variation pattern and evolution. On this basis, the impact of the landscape and environmental factors on the housing price differentiation was analyzed and its differences in their influence on residential submarkets were investigated. As the study object included ordinary commercial houses, villas, high-end commercial and residential apartments, housing-reformation quarters, indemnificatory houses and cottages, that is all housing types market transactions can be performed on, the investigation is much more reliable compared to other studies that analyzed just the ordinary commercial housing.

\section{Data and methodologies}

\subsection{Determination of the study area and research units}

Yangzhou is located in the middle of Jiangsu province, the north shore of the lower reaches of the Yangtze River and the important city in the economic circle of the Yangtze River delta (Figure 1). In this paper Yangzhou downtown (hereinafter referred to as Yangzhou City) was selected as the study area. The spatial extent of the study area was defined from the circle-shaped space and the fan-shaped space, respec-

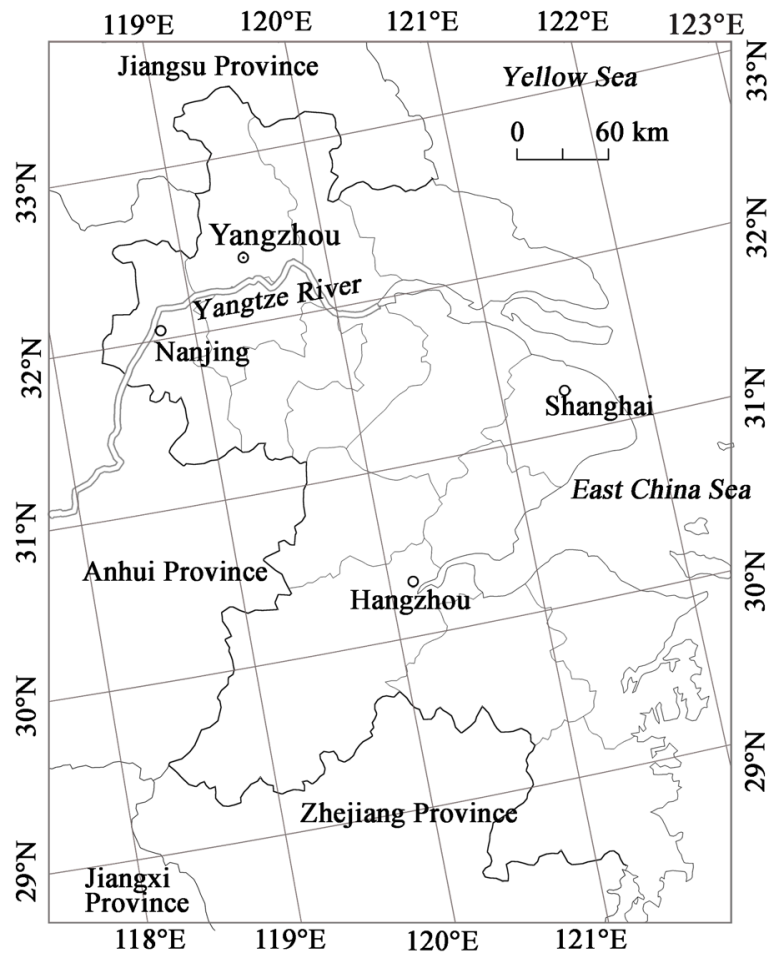

Figure 1 Yangzhou City in Yangtze River Delta 
tively (Figure 2) and residential construction age, the building type and other factors were considered. Therefore, the analyzed area could be provided with the full coverage study. The basic principles of the cell division were: year built, number of levels/floors and grades and other architectural features unique within the same residential cell. Since there are not many cottages in the Ancient Urban Area, they were merged into one research unit; eventually 1094 research units were formed (2012).

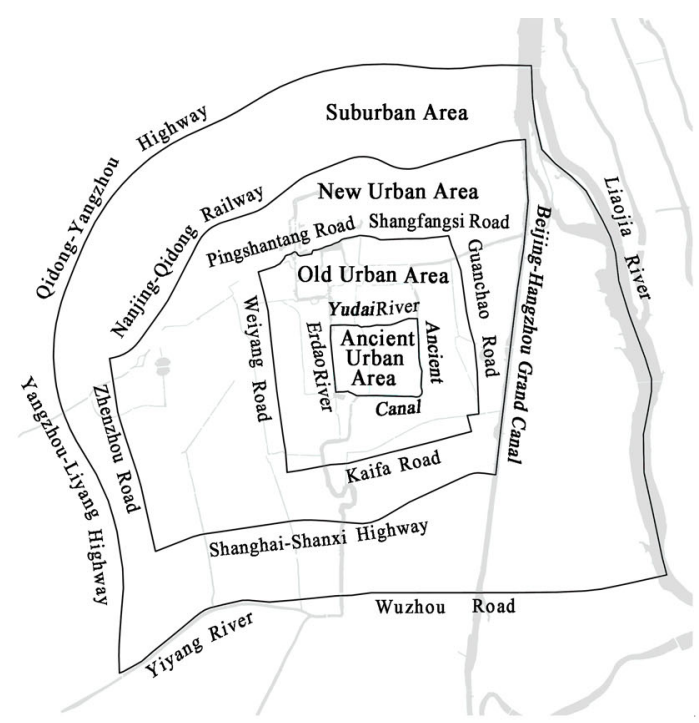

(a) Area divisions by concentric structure

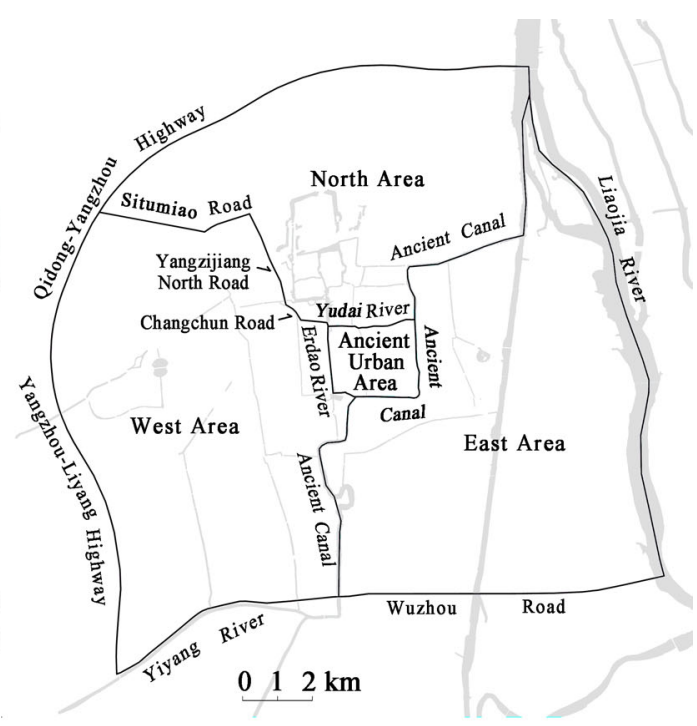

(b) Area divisions by fan structure

Figure 2 The spatial scope of two types (concentric structure and fan structure) in Yangzhou

\subsection{Data sources and processing}

\subsubsection{Housing prices data sources and processing}

Housing prices quoted in this paper indicate the average listing price of each residential Quarter was determined in the following way: for an existing building, the use of the second-hand house listing price was quoted; for the under-construction residential building the developer opening price was quoted. The 2011 housing price was calculated as the annual average of data derived from the Yangzhou second-hand estate market website (http://www. yz2shou.com/fdc.htm) (acquisition time: November 2011). The 2012 data was derived from the City House-Yangzhou website (http://yz.cityhouse.cn) as the average of the June-August 2012 prices (acquisition time: September 2012), and also from the Soufun website (http:// esf.yz. soufun.com), the 58 Tongcheng website (http://yz.58.com/xiaoqu) and other websites; on these bases the two-year database was checked and supplemented. The 2001-2010 data was derived from the residential sales advertising published in Yangzhou Evening News in October-December of the above-mentioned years, with the 2001 and 2002 data derived from the July-December advertising. Each residential cell usually has several dozens of supporting sample data; altogether for the period 2001-2010 there are 47,198 data samples. The number of the housing samples and residential quarters are given in Table 1. 
Table 1 Number of housing samples and residential quarters in Yangzhou City (2001-2012)

\begin{tabular}{ccccccccccccc}
\hline \multicolumn{1}{c}{ Year } & 2001 & 2002 & 2003 & 2004 & 2005 & 2006 & 2007 & 2008 & 2009 & 2010 & 2011 & 2012 \\
\hline Housing samples & 4183 & 3575 & 3053 & 4223 & 4022 & 3514 & 3057 & 5332 & 7813 & 8426 & - & - \\
Residential quarters & 346 & 352 & 430 & 459 & 458 & 485 & 520 & 614 & 612 & 853 & 1070 & 1094 \\
Coverage rate (\%) & 71.30 & 66.32 & 67.91 & 68.63 & 68.76 & 82.24 & 73.20 & 77.60 & 79.46 & 97.83 & 100 & 100 \\
\hline
\end{tabular}

2.2.2 Other relevant data sources and their processing

Data on the residential types and their year of construction were obtained mainly through: (1) the assistance of the Yangzhou City Housing Security Management Bureau and its various branches; (2) the on-the-spot cell site visits and inquiries; (3) inquiries to the real estate agents; (4) inquiries to the relevant real estate information websites. Data related to the residential land area was calculated using the GIS technology. Residential building area was calculated on the basis of land area and floor area ratio. These data are publicized by the Yangzhou City Planning Bureau for residential construction projects.

\subsection{Research methods}

2.3.1 Construction of the Global Differentiation Index (GDI) to measure the housing price differentiation

In order to measure the degree of differentiation of the general housing prices, the coefficient of variation $(\mathrm{CV})$, the Theil index $(\mathrm{T})$, the general entropy index (GE), the Atkinson index (A) and other differentiation indices can be applied. However, as the basic principles of these indices are not the same, the obtained results may vary. For this reason, in this paper the above indices were integrated to create finally a new overall differentiation measure index called the Global Differentiation Index (GDI). The resulting value of that index can simultaneously reflect information on the spatial differentiation given by the four conventional indices, moreover the obtained results are more fixed, fully reflecting the degree of changes in the regional-scale or city-scale overall differentiation of housing prices. The calculation process is as follows:

(1) The four traditional indices calculated separately are (Wang et al., 2012):

Coefficient of variation:

$$
C V=\sqrt{\sum_{i=1}^{n}\left(x_{i}-\mu\right)^{2} / n} / \mu
$$

The Theil coefficient:

$$
T=\frac{1}{n} \sum_{i=1}^{n} \frac{x_{i}}{\mu} \log \frac{x_{i}}{\mu}
$$

The general entropy index:

$$
G E=\frac{1}{n} \sum_{i=1}^{n} \log \left(\mu / x_{i}\right)
$$

The Atkinson index:

$$
A=1-\left[\frac{1}{n} \sum_{i=1}^{n}\left(\frac{x_{i}}{\mu}\right)^{1-\varepsilon}\right]^{1 /(1-\varepsilon)}
$$


where $x_{i}$ is the $i$-th cell housing price, $\mu$ is the average housing price, $n$ is the number of residential quarters, $\varepsilon$ is the parameter related to the value of the sensitivity variance, $\varepsilon>0$, the greater the $\varepsilon$ is, the larger weight given to a relatively low-price cell; $\varepsilon$ usually takes values of 0.5 and 2 (Atkinson, 1970), in this paper the value of $\varepsilon$ was 0.5 .

(2) Construction of the housing price Global Differentiation Index (GDI)

On the basis of the results obtained using the above-described four traditional indices the housing price Global Differentiation Index (GDI) was constructed as follows:

$$
G D I=f(C V, T, G E, A)
$$

In comparison of the multiple time periods the information entropy can be used to determine the weights of these indices (Chen et al., 2012).

2.3.2 The use of the hedonic price model to analyze the factors affecting the landscape and the environment and their implicit prices

The semi-log form of the hedonic price model is one of the most commonly used methods applied in analysis of the factors affecting housing prices. It can be expressed as (Hong and Li, 2011):

$$
\ln P=\alpha_{0}+\Sigma \alpha_{i} Z_{i}+\varepsilon
$$

where $P$ is the dependent variable of urban housing prices, $\alpha_{0}$ is undetermined coefficient, $\alpha_{i}$ is regression coefficient, $\varepsilon$ is random variable, $Z_{i}$ is independent variable, a housing characteristics score. In this paper, a particular independent variable characteristic was evaluated by a number of indicators:

$$
Z=\Sigma w_{j} z_{j}
$$

where $z_{j}$ is the index score used for the evaluation of $Z$ characteristics, $w_{j}$ is the weight; in the calculations the entropy method was still used.

\section{Spatial differentiation of housing prices in Yangzhou City}

Spatial differentiation of housing prices is mainly embodied in the following two aspects: one is the general differentiation degree measured by GDI, and the other is spatial differentiation pattern reflected by GIS.

\subsection{The general differentiation degree and evolution of housing prices}

On the basis of the entropy method the weights of CV, T, GE and A were determined as $0.3040,0.2623,0.2051$ and 0.2286 , respectively. The values of the GDI index for each year calculated according to the given expression are shown in Table 2 and Figure 3.

The obtained results show that the spatial differentiation of housing prices in Yangzhou

\begin{tabular}{|c|c|c|c|c|c|c|c|c|c|c|c|c|}
\hline Year & 2001 & 2002 & 2003 & 2004 & 2005 & 2006 & 2007 & 2008 & 2009 & 2010 & 2011 & 2012 \\
\hline$G D I$ & 0.2500 & 0.1878 & 0.2120 & 0.1810 & 0.1988 & 0.2237 & 0.2421 & 0.2733 & 0.2324 & 0.2883 & 0.3613 & 0.3694 \\
\hline $\begin{array}{l}\text { Average housing } \\
\text { price }\end{array}$ & 1564 & 1866 & 2443 & 2949 & 3163 & 3387 & 4420 & 4356 & 5517 & 7500 & 8178 & 8130 \\
\hline $\begin{array}{l}\text { Annual rate of } \\
\text { growth (\%) }\end{array}$ & - & 19.34 & 30.92 & 20.7 & 7.25 & 7.09 & 30.49 & -1.47 & 26.66 & 35.95 & 9.05 & -0.59 \\
\hline
\end{tabular}
City had the fluctuating-style, generally upward trend. From 2001 to 2004 the trend was

Table 2 The calculated values of the housing prices GDI in Yangzhou (2001-2011) 
declining, but increased significantly from 2004 to 2008, then decreased, and again increased dramatically since 2009. These changes are, to a certain extent, related with the annual rate of growth of average housing prices in Yangzhou City, especially in 2008 and 2012, when the negative growth in housing price differentiation occurred. This shows that when housing prices fell, some types of housing also fell significantly, while others

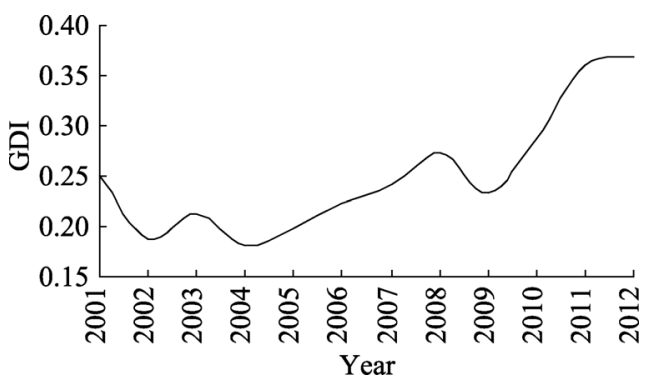

Figure 3 The fluctuation of GDI on housing price in Yangzhou since 2001 remained relatively unchanged, resulting in more intense price heterogeneity.

\subsection{Spatial differentiation pattern and evolution of housing prices}

For each analyzed year all residential quarters are divided into five categories depending on their housing prices: the high-price districts $(10 \%$ of the total), the middle-higher price districts $(20 \%)$, the middle-price districts $(40 \%)$, the middle-lower price districts $(20 \%)$ and the low price districts $(10 \%)$.

Figure 4 shows that during 12 years the Yangzhou City housing prices showed a general
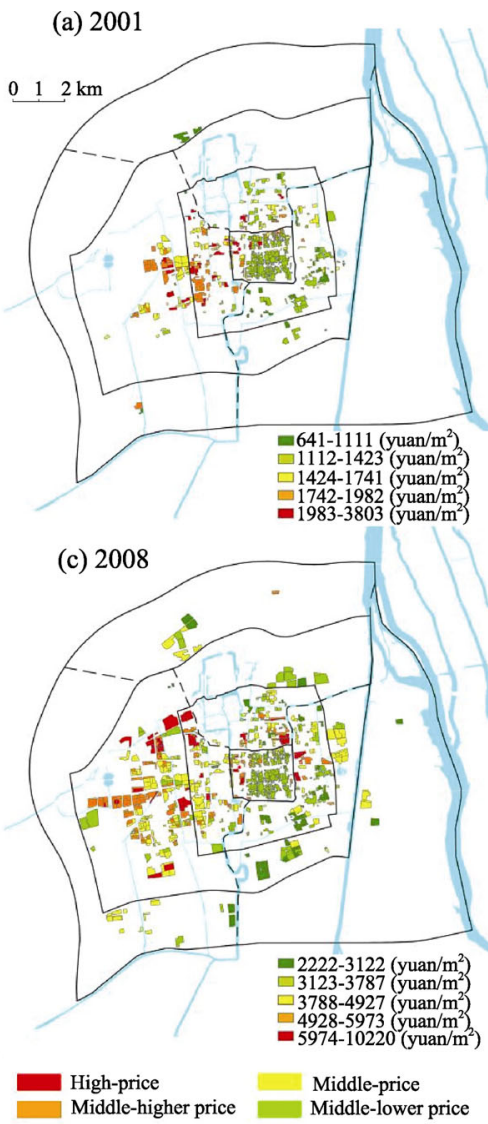

(b) 2004

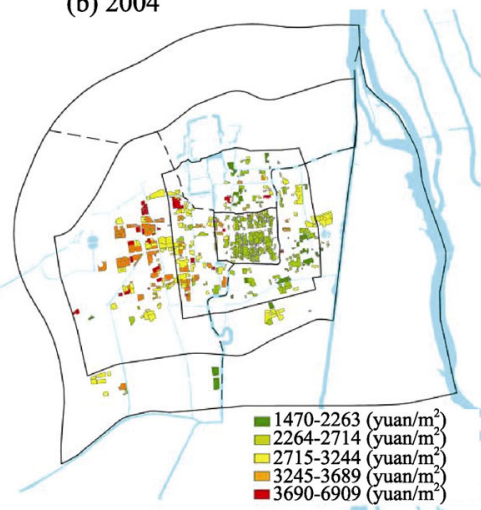

(d) 2012

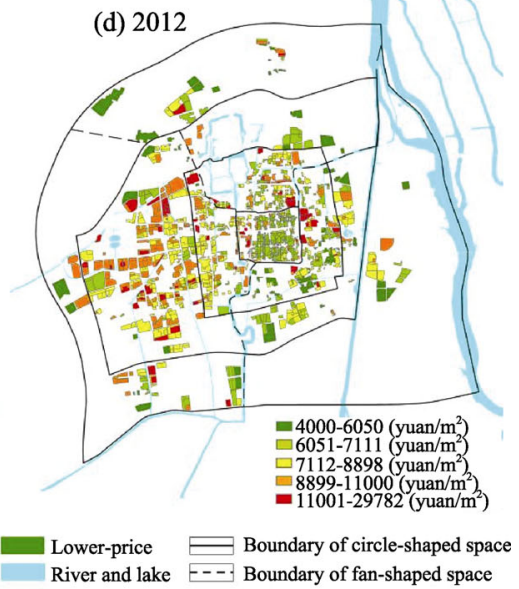

Figure 4 The spatial differentiation pattern of housing prices in Yangzhou since 2001 
"high-price west to low-price east" fan-shaped spatial differentiation pattern. Along with the increase in new residential quarters the differentiation pattern became more complex: the concentrated pattern of similar-price cells in 2001 transformed into the relatively decentralized one in 2012. Moreover, while in 2001 the housing prices of the western districts were generally higher and the eastern lower, the northern districts and the Ancient Urban Area with generally low prices but also the high-and-low price crisscross pattern, the high-priced residential quarters were mainly in the western districts of the Old Urban Area and the New Urban Area. In 2004 the high-priced western districts apparently moved outside towards the New Urban Area, while in the other areas essentially the same pattern was preserved. In 2008 the high-priced residential quarters continued to move westwards, the high-priced residential area surrounding the Slender West Lake increased, expensive residential quarters began to appear in the eastern and northern districts, but basically were distributed in the Old Urban Area along the ancient Grand Canal. In 2012 there were more high-priced residential quarters in the eastern and northern districts and the trend of intertwining different price housing became more apparent.

\section{Landscape and environmental impact on spatial differentiation of the Yangzhou City housing prices}

\subsection{Housing characteristics and establishment of their evaluation index system}

In order to thoroughly analyze the impact of the urban landscape and environment on the housing prices, in the paper the hedonic price model was divided into five parts: the hedonic price model of the building (architectural) characteristics, the neighborhood characteristics, the location characteristics, the landscape characteristics and the environmental characteristics. Among them, the building characteristics, the neighborhood characteristics, the location characteristics can serve as the control variables in the hedonic price model regression process. According to the forecast on the impact of each variable on housing prices, a scoring system from low to high (from 1 to 9) points was applied. Details are given in Table 3.

\subsection{Evaluation of spatial characteristics of landscape and environment}

\subsubsection{Evaluation of natural landscape characteristics}

The green areas of Yangzhou City were evaluated at two levels: the first one refers to the role of major parks on the prices of the surrounding residential quarters. The second level refers to the other types of parks and green areas (Figure 5a). The waterfront landscapes can also be considered at two levels: the first one which refers to major rivers and lakes, relatively significantly influencing the surrounding residential prices, as beautiful landscape including: the Ancient Canal, the Beijing-Hangzhou Grand Canal, the Liaojia River, the Slender West Lake, the Hehua Lake, the Mingyue Lake, the Qujiang Lake. The second level refers to the other landscape rivers and lakes (Figure 5b). Calculations proved that the weight of the waterfront landscape was slightly higher than that of the green areas.

\subsubsection{Evaluation of environmental characteristics}

This included evaluation of industrial and warehousing areas, which may be a potential 
Table 3 Characteristics of urban housing prices and the scoring variables

\begin{tabular}{|c|c|c|}
\hline Evaluation indices & Perspective and scores (from highest to lowest) & Weight \\
\hline \multicolumn{3}{|l|}{$\mathrm{Z}_{1}$ Building characteristics } \\
\hline $\mathrm{z}_{11}$ Housing types & $\begin{array}{l}\text { Villas (9), ordinary commercial housing or high-end residential apartments } \\
\text { (7), old public housing (5), affordable housing (3), collective property rights } \\
\text { housing (1) }\end{array}$ & 0.2536 \\
\hline $\mathrm{z}_{12}$ Certificate expires & 70 years (9), 40 years (5), collective property rights (1) & 0.2418 \\
\hline $\mathrm{z}_{13}$ Construction times & 2011-2012 (9), 2006-2010 (7), 1999-2005 (5), 1991-1998 (3), before 1990 (1) & 0.3146 \\
\hline $\begin{array}{l}\mathrm{z}_{14} \text { Grade of residential } \\
\text { quarters }\end{array}$ & $\begin{array}{l}\text { High-grade (9), middle-higher grade (7), middle-grade (5), middle-lower } \\
\text { grade (3), low-grade (1) }\end{array}$ & 0.1899 \\
\hline \multicolumn{3}{|c|}{$Z_{2}$ Neighbourhood characteristics } \\
\hline $\begin{array}{l}\mathrm{z}_{21} \text { Accessibilities of basic } \\
\text { education }\end{array}$ & $\begin{array}{l}\text { Key school districts (9), outside of key school districts but within } 1000 \mathrm{~m} \text { of } \\
\text { key schools (5), others (1) }\end{array}$ & 0.3982 \\
\hline $\begin{array}{l}\mathrm{z}_{22} \text { Accessibilities of } \\
\text { medical, culture and sport }\end{array}$ & $\begin{array}{l}\text { High-accessibilities (9), middle-higher accessibilities (6), middle- } \\
\text { accessibilities (3), low-accessibilities (1) }\end{array}$ & 0.2316 \\
\hline $\begin{array}{l}\mathrm{z}_{23} \text { Accessibilities of main } \\
\text { business district }\end{array}$ & Within $2 \mathrm{~km}(9), 2-3 \mathrm{~km}(5)$, outside $3 \mathrm{~km}$ (1) & 0.3702 \\
\hline \multicolumn{3}{|l|}{$\mathrm{Z}_{3}$ Location characteristics } \\
\hline $\mathrm{z}_{31}$ Concentric positions & $\begin{array}{l}\text { Inner city (ancient urban area) (9), transitional area (old urban area) (7), outer } \\
\text { city (new urban area) (5), suburban area (3), outer suburban area (1) }\end{array}$ & 0.5601 \\
\hline $\mathrm{Z}_{32}$ Block positions & Superior blocks (9), ordinary blocks (5), worse blocks (1) & 0.3583 \\
\hline $\begin{array}{l}\mathrm{z}_{33} \text { Main road accessibili- } \\
\text { ties }\end{array}$ & $\begin{array}{l}\text { Within } 300 \mathrm{~m} \text { of major roads and } 100 \mathrm{~m} \text { of ordinary roads }(9) \text {, within } 300 \mathrm{~m} \\
\text { of major roads (5), } 100 \mathrm{~m} \text { of ordinary roads (3), others (1) }\end{array}$ & 0.0816 \\
\hline
\end{tabular}

$\mathrm{Z}_{41}$ Green landscape levels Within $200 \mathrm{~m}$ of major parks $(9), 200-400 \mathrm{~m}$ of major parks and within 200 areas (3), outside $400 \mathrm{~m}$ of major parks or outside $200 \mathrm{~m}$ of green areas (1)

Within $200 \mathrm{~m}$ of major river and lake (9), 200-400 m of major river (lake)

$\mathrm{Z}_{42}$ Waterfront landscape levels and within $200 \mathrm{~m}$ of ordinary river (8), 200-400 m of major river and lake (5), within $200 \mathrm{~m}$ of ordinary river (3), outside $400 \mathrm{~m}$ of major river (lake) or outside $200 \mathrm{~m}$ of ordinary river (1)

\section{$\mathrm{z}_{51}$ Impact of productive lands \\ $\mathrm{Z}_{52}$ Impact of municipal facilities \\ $\mathrm{Z}_{53}$ Impact of urban vil- lages}

$\mathrm{Z}_{5}$ Environmental characteristics
No impact (9), middle impact (5), serious impact (1)

No impact (9), middle impact (5), middle-higher impact (3), serious impact (1)

0.0434

Outside $200 \mathrm{~m}$ of major urban villages (9), 100-200 m of major urban villages (5), within $100 \mathrm{~m}$ of major urban villages (1)

source of different kinds of pollution, as noise pollution, air pollution and so on. Among them, the third type of industrial areas (M3) was considered as a source of serious pollution affecting most seriously and having the highest influence on the surrounding residential quarters; the warehouse areas and the first type of industrial areas (M1) had relatively low influence on the surrounding residential quarters; the second type of industrial areas (M2) had the middle-level influence on the surrounding environment (Table 4). In order to calculate their impact on the residential quarters, the above-described three types of areas were given weights of $0.5,0.4$ and 0.1 , respectively; the higher the score obtained, the lower the impact produced (Figure 6). 


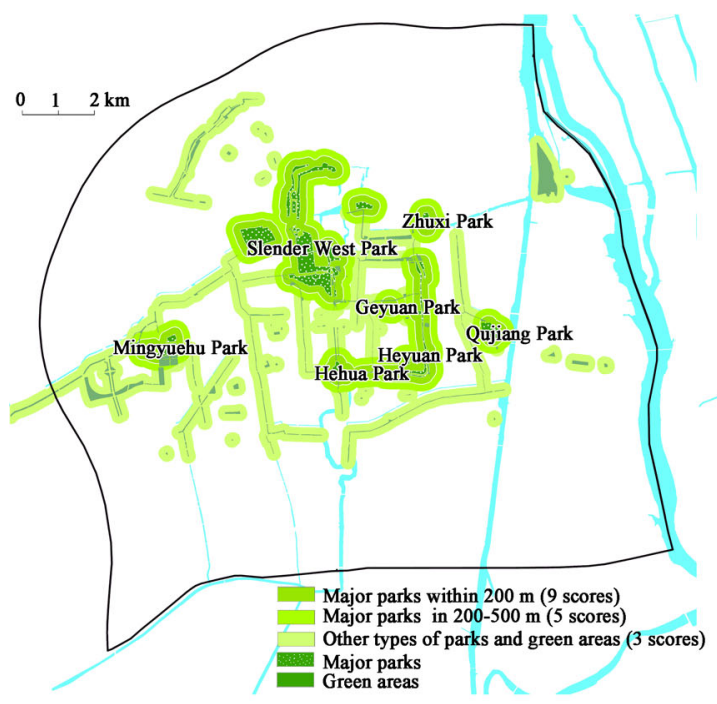

(a) Green landscape

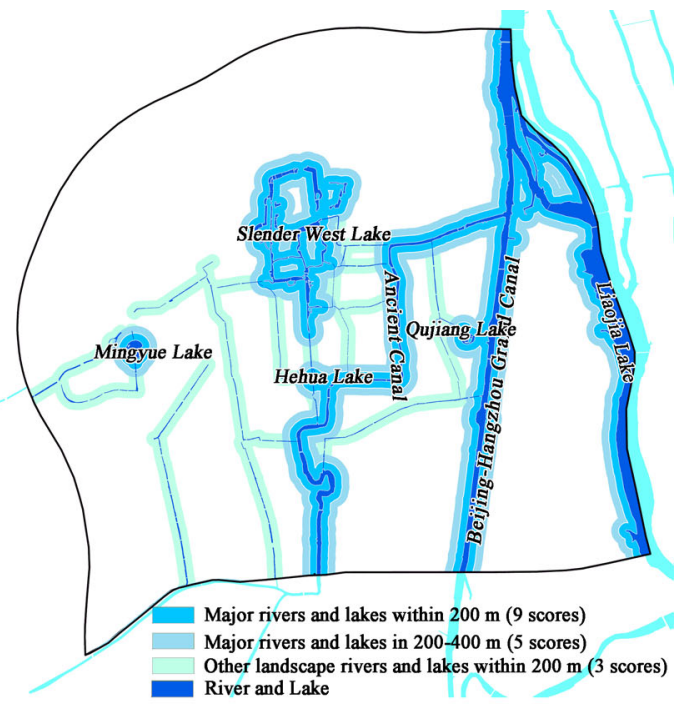

(b) Waterfront landscape

Figure 5 Green landscape and waterfront landscape sphere of influence in Yangzhou

Table 4 Productive land impact on the surrounding environment scoping

\begin{tabular}{lcccc}
\hline \multicolumn{1}{c}{ Types } & 9 point & 5 point & 1 point & Weight \\
\hline M3 (serious polluting manufacture areas) & Outside $500 \mathrm{~m}$ & $250-500 \mathrm{~m}$ & Within $250 \mathrm{~m}$ & 0.5 \\
M2 (moderate polluting manufacture areas) & Outside $300 \mathrm{~m}$ & $150-300 \mathrm{~m}$ & Within $150 \mathrm{~m}$ & 0.4 \\
M1 (slightly polluting manufacture areas) or W (warehousing areas) & Outside $200 \mathrm{~m}$ & $100-200 \mathrm{~m}$ & Within $100 \mathrm{~m}$ & 0.1 \\
\hline
\end{tabular}

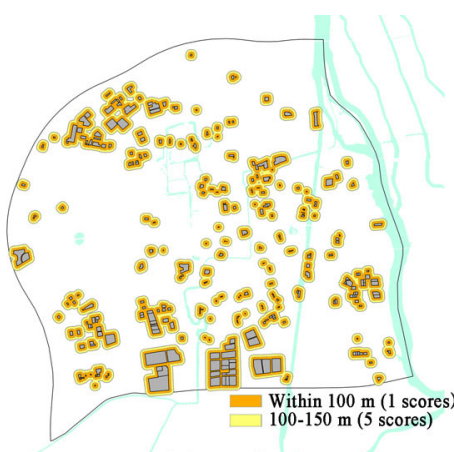

(a) $\mathrm{M} 1 / \mathrm{W}$

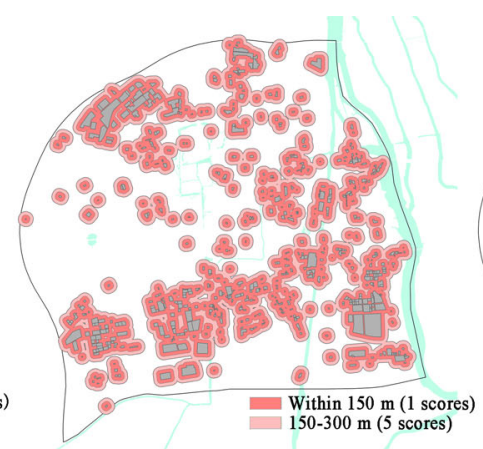

(b) $\mathrm{M} 2$

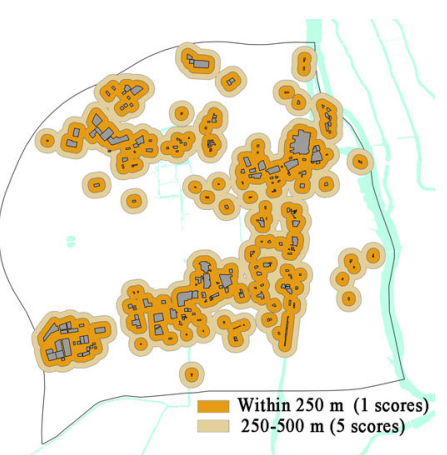

(c) M3

Figure 6 Productive land sphere of influence in Yangzhou

Municipal facilities which have impact on the environment of the residential quarters include: high voltage corridors (35 KV and higher), transformer substations, waterworks, gas stations and gas regulator stations, petrol stations, sewage treatment plants, waste transfer stations and funeral sites (including cemetery and crematorium). Radiuses of influence of these facilities are defined in Table 5. The applied scoring method of municipal facilities with environmental impact on residential quarters is as follows: areas with none of the above facilities got 9 scores, areas with one kind of facilities got 5 scores, areas with two facilities got 3 scores and areas with three or more facilities got 1 score (Figure 7a). 
Table 5 The radius of influence of utility facilities in Yangzhou

\begin{tabular}{ccccc}
\hline Types & High voltage corridors & Transformer substations & Waterworks & Gas stations \\
\hline The radius of influence $(\mathrm{m})$ & 100 & 300 & 300 & 300 \\
Types & Petrol stations & Sewage treatment plants & Waste transfer stations & Funeral sites \\
The radius of influence $(\mathrm{m})$ & 150 & 2000 & 200 & 1000 \\
\hline
\end{tabular}



(a) Utility facilities

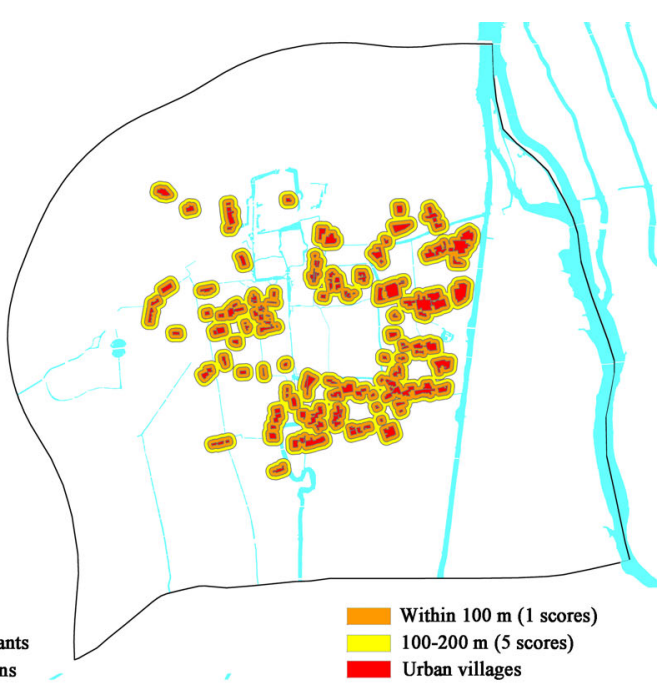

(b) Urban villages

Figure 7 The extent of impact of municipal facilities and urban villages on the Yangzhou City environment

Moreover, studies show that urban villages also have significant negative influence on the surrounding residential prices (Song and Zenou, 2012). Consequently, in this paper three scoring grades were given depending on the impact of the urban villages: 1 score for areas within the radius of $100 \mathrm{~m}$ (seriously affected); 5 scores for areas within 100-200 m (moderately-affected) and 9 scores for areas above $200 \mathrm{~m}$ (not affected) (Figure 7b).

\subsection{Degree of the natural landscape and environmental influence on housing prices}

4.3.1 Influence of the natural landscape and environment on all types of residential quarters

Using the above-described five characteristics and the hedonic price model the impact of each landscape and environmental characteristics on housing prices was analyzed. Assuming similar housing choices and preferences of homebuyers in Yangzhou City, the housing prices were characterized by five large functions.

Using the regression model obtained goodness-of-fit statistics $R$ of the hedonic price model was 0.651 , while the adjusted $R^{2}$ was 0.422 . Therefore, the overall model fitted well. At 0.000 significance level $F=191.214$, indicating that the regression model was extremely significant. The values of standard regression coefficients of the main five factors are given in Table 6. Table 6 shows that the natural landscape and environment significantly influence the housing prices. 
Table 6 Regression coefficients of Yangzhou City housing prices based on five main factors

\begin{tabular}{lccccc}
\hline \multicolumn{1}{c}{ Types } & $\begin{array}{c}\text { Unstandardized } \\
\text { coefficients }\end{array}$ & $\begin{array}{c}\text { Standard } \\
\text { Errors }\end{array}$ & $\begin{array}{c}\text { Standardized } \\
\text { coefficients }\end{array}$ & $t$ & Sig. \\
\hline Undetermined coefficient $\left(\alpha_{0}\right)$ & 8.080 & 0.035 & - & 231.712 & 0.000 \\
Building characteristics & 0.095 & 0.004 & 0.741 & 25.480 & 0.000 \\
Neighbourhood characteristics & 0.011 & 0.003 & 0.098 & 3.243 & 0.001 \\
Location characteristics & 0.049 & 0.005 & 0.354 & 10.544 & 0.000 \\
Landscape characteristics & 0.011 & 0.002 & 0.105 & 4.603 & 0.000 \\
Environmental characteristics & 0.010 & 0.002 & 0.101 & 4.102 & 0.000 \\
\hline
\end{tabular}

Based on the values in Table 6, the hedonic regression model was constructed as follows:

$$
\ln P=8.080+0.095 x_{1}+0.011 x_{2}+0.049 x_{3}+0.011 x_{4}+0.010 x_{5}
$$

The model shows that when the characteristics remain unchanged, every $1 \%$ increase in the scoring of the natural landscape characteristics results in the $1.1 \%$ increase of the housing prices, while every $1 \%$ increase in the scoring of the environmental characteristics results in the $1.0 \%$ increase of the housing prices. This proves that the landscape and the environment have significant externalities on the housing prices.

4.3.2 Differences in the influence of the natural landscape and environment on residential submarket housing prices

According to Yangzhou City real estate market characteristics and based on housing type five categories of residential submarket can be distinguished: ordinary commercial houses, indemnificatory houses (including unit dormitories, old public houses, affordable houses, resettlement houses), high-end commercial and residential apartments, villas (including independent villas, semi-detached villas, superimposed villas) and cottages (including collective property rights and the Ancient Urban Area cottages). Table 7 shows that the three types of submarket models, that is: ordinary commercial houses, indemnificatory houses and villas have better goodness-of-fit statistics $\mathrm{R}$ than if not divided into submarkets.

Table 7 Landscape and environmental effects on housing submarkets

\begin{tabular}{|c|c|c|c|c|c|c|c|c|c|}
\hline \multirow{2}{*}{$\begin{array}{l}\text { Types of housing } \\
\text { submarkets }\end{array}$} & \multirow{2}{*}{$R$} & \multirow{2}{*}{$\begin{array}{c}\text { Adjusted } \\
R^{2}\end{array}$} & \multirow{2}{*}{$\begin{array}{l}\text { Standard } \\
\text { errors }\end{array}$} & \multirow{2}{*}{$F$} & \multirow{2}{*}{ Sig. } & \multicolumn{2}{|c|}{$\begin{array}{l}\text { Natural landscape } \\
\text { characteristics }\end{array}$} & \multicolumn{2}{|c|}{$\begin{array}{l}\text { Environmental } \\
\text { characteristics }\end{array}$} \\
\hline & & & & & & $\begin{array}{c}\mathrm{B}(\text { Unstandardized } \\
\text { coefficients })\end{array}$ & Sig. & $\begin{array}{l}\text { B (Unstandardized } \\
\text { coefficients) }\end{array}$ & Sig. \\
\hline $\begin{array}{l}\text { Ordinary commer- } \\
\text { cial houses }\end{array}$ & 0.763 & 0.578 & 0.122 & 131.249 & 0.000 & $0.015^{* * *}$ & 0.000 & 0.002 & 0.477 \\
\hline $\begin{array}{l}\text { Indemnificatory } \\
\text { houses }\end{array}$ & 0.680 & 0.456 & 0.116 & 73.739 & 0.000 & $0.007^{* * *}$ & 0.003 & 0.002 & 0.473 \\
\hline Villas & 0.539 & 0.248 & 0.289 & 6.863 & 0.000 & $0.028^{*}$ & 0.059 & $0.040^{* *}$ & 0.018 \\
\hline $\begin{array}{l}\text { High-end commer- } \\
\text { cial and residential } \\
\text { apartments }\end{array}$ & 0.461 & 0.026 & 0.239 & 1.136 & 0.372 & -0.014 & 0.650 & 0.028 & 0.260 \\
\hline Cottages & 0.716 & 0.504 & 0.115 & 56.669 & 0.000 & 0.005 & 0.124 & $0.019^{* * *}$ & 0.000 \\
\hline
\end{tabular}


This proves that after the sub-division of the residential market, more accurate depiction of the prices was resulted. Except the high-end commercial and residential apartments submarket, the rest of the regression model was very significant. The influence of natural landscape and environmental characteristics on different housing submarkets is different: in ordinary commercial houses and security markets, the impact of natural landscape characteristics on housing prices is very obvious; $1 \%$ increase of the natural landscape characteristics results in $1.5 \%$ increase of the ordinary commercial housing price and $0.7 \%$ increase of the indemnificatory housing price. At the same time, an increase of the environmental characteristics has no evidence on the housing prices of these two submarkets. As to the villa submarkets, there is an influence of both natural landscape and environmental characteristics, especially the influence of the environmental characteristics is more obvious: every $1 \%$ increase in the environmental characteristics results in $4.0 \%$ increase of the villa prices. As to the cottages submarket, the impact of the environment on the price is most significant, while the natural environment impact is not obvious. Every $1 \%$ increase of the environmental scoring results in $1.9 \%$ increase of the cottage price. The impact of the natural landscape and environmental characteristics of the high-end commercial and residential apartments is not obvious, this is due to the location of the high-end commercial and residential apartments which is the core element determining the price. This suggests that after the division into the residential submarkets, there were changes in the landscape and environment externalities on the housing prices, and also that the impacts on different housing types are different.

\section{Conclusions and discussion}

\subsection{Increasing differentiation trend and dispersed spatial distribution of housing prices}

In the background of continued and short-period fluctuated rising of average housing price in Yangzhou City, spatial differentiation of housing prices had an overall growing, fluctuated-type trend coupling with the average annual growth rate of housing prices; from west to east the spatial differentiation pattern of housing prices became more complex, the spatially concentrated similar-price districts became relatively dispersed. This proves that since the reform of the housing system China's urban housing prices experienced the trend of spatial variation, which is an inevitable phenomenon in this stage of development. It is inevitable that the degree of these differences increases with the development of the real estate market, but also with the environment and changeable real estate market fluctuations.

\subsection{Significant impact of landscape and environment on spatial differentiation of housing prices}

The natural landscape and environment have significant externalities on changes of housing prices. The case of Yangzhou City shows that beautiful natural landscapes and healthy environment can significantly enhance the value of the surrounding residential quarters. When the landscape or environmental characteristics are upgraded by $1 \%$, then the house prices increase by $1.1 \%$ and $1.0 \%$, respectively. Elements that constitute the natural landscape, the influence of the waterfront landscape is slightly stronger than the influence of green space; among the evaluated environmental elements the impact of the municipal facilities is rela- 
tively the lowest, while that of productive lands and urban villages is more significant.

The influence of the landscape and environmental factors on different types of housing submarkets is different: the natural landscape characteristics have very clear influence on ordinary commercial houses and indemnificatory houses; $1 \%$ increase of the natural landscape characteristics results in $1.5 \%$ increase of the ordinary commercial housing price and $0.7 \%$ increase of the indemnificatory housing price; every $1 \%$ increase in the environmental characteristics results in up to $4.0 \%$ increase of the villa prices and $1.9 \%$ increase in the cottage price. At the same time, the impact of the landscape and environmental features on high-end commercial and residential apartment is not obvious. This proves that by dividing the housing submarket, changes in the landscape and environmental characteristics results in different impacts on different housing types. Therefore, the study on the influence of the landscape and environmental externalities on spatial differentiation of urban housing prices should put more emphasis on the sub-division of the market and also classification methods should be investigated.

\section{References}

Atkinson A B, 1970. On the measurement of inequality. Journal of Economic Theory, 2(3): 244-263.

Bourassa S C, Hoesli M, Peng V S, 2003. Do housing submarkets really matter? Journal of Housing Economics, 12(1): 12-28.

Cavailhès J, Brossard T, Foltête J C et al., 2009. GIS-based hedonic pricing of landscape. Environmental and Resource Economics, 44(4): 571-590.

Chang J S, Kim D J, 2013. Hedonic estimates of rail noise in Seoul. Transportation Research Part D: Transport and Environment, 19: 1-4.

Chen Mingxing, Lu Dadao, Zha Liangsong, 2010. The comprehensive evaluation of China's urbanization and effects on resources and environment. Journal of Geographical Sciences, 20(1): 17-30.

Chen Yun, Wang Hao, 2011. Construction and application of bipartite recursive algorithm based on kernel density estimation: A new non-parametric method to measure the given income population scale. Statistics \& Information Forum, 26(9): 3-8. (in Chinese)

Chhetri P, Han J H, Corcoran J, 2009. Modelling spatial fragmentation of the Brisbane housing market. Urban Policy and Research, 27(1): 73-89.

Chu Honejay, Liau Churnjung, Lin Chaohung et al., 2012. Integration of fuzzy cluster analysis and kernel density estimation for tracking typhoon trajectories in the Taiwan region. Expert Systems with Applications, 39(10): 9451-9457.

Davis L W, 2011. The effect of power plants on local housing values and rents. Review of Economics and Statistics, 93(4): 1391-1402.

Des R F, Lagana A, 1996. Shopping centres and house values: An empirical investigation. Journal of Property Valuation Investment, 14(4): 41-62.

Duarte C M, Tamez C G, 2009. Does noise have a stationary impact on residential values? Journal of European Real Estate Research, 2(3): 259-279.

Fang Chuanglin, Guan Xingliang, Lu Shasha et al., 2013. Input-output efficiency of urban agglomerations in China: An application of data envelopment analysis (DEA). Urban Studies, 50(13): 2766-2790.

Fang Xiaoping, Ding Sibao, 2012. Geographical spread of urban house price in China and its regional externality. Scientia Geographica Sinica, 32(2): 143-148. (in Chinese)

Feng Changchun, Li Weixuan, Zhao Fanfan, 2011. Influence of rail transit on nearby commodity housing prices: A case study of Beijing subway line five. Acta Geographica Sinica, 66(8): 1055-1062. (in Chinese)

Gamper-Rabindran S, Timmins C, 2012. Does cleanup of hazardous waste sites raise housing values? Evidence of spatially localized benefits. Journal of Environmental Economics and Management. Working Paper EE, $12-03$.

Goodman A C, Thibodeau T G, 2003. Housing market segmentation and hedonic prediction accuracy. Journal of Housing Economics, 12(3): 181-201.

Ham Y J, Maddison D J, Elliott R J, 2013. The valuation of landfill disamenities in Birmingham. Ecological Economics, 85(C): 116-129 
He C J, Wang Z, Guo H C et al., 2010. Driving forces analysis for residential housing price in Beijing. Procedia Environmental Sciences, 2: 925-936.

Helbich M, Jochem A, Mücke W et al., 2013. Boosting the predictive accuracy of urban hedonic house price models through airborne laser scanning. Computers, Environment and Urban Systems, 39(5) :81-92.

Hong Guozhi, LI Xun, 2011. Border effect of inner city: Research based on spatial spillover of real estate price. Acta Geographica Sinica, 66(4): 468-476. (in Chinese)

Hong Tao, 2009. A comparative research on the relationship of housing prices among cities: Evidence from Yangtze River Delta and Jing-Jin-Ji Area. Statistics \& Information Forum, 24(4): 58-62. (in Chinese)

Jim C Y, Chen W Y, 2007. Consumption preferences and environmental externalities: A hedonic analysis of the housing market in Guangzhou. Geoforum, 38(2): 414-431.

Koramaz T K, Dokmeci V, 2012. Spatial determinants of housing price values in Istanbul. European Planning Studies, 20(7): 1221-1237.

Kuethe T H, 2012. Spatial fragmentation and the value of residential housing. Land Economics, 88(1): 16-27.

Landry C E, Hindsley P, 2011. Valuing beach quality with hedonic property models. Land Economics, 87(1): 92-108.

Li Xun, Fu Wenying, 2010. Investigation of the capitalization of municipal government infrastructure investment on housing market: Hedonic model based on Guangzhou housing price data. Geographical Research, 29(7): 1269-1280. (in Chinese)

Machin S. Houses and schools: Valuation of school quality through the housing market. Labour Economics, 2011, 18(6): 723-729

Mahan B L, Polasky S, Adams R M, 2000. Valuing urban wetlands: A property approach. Land Economics, 76(1): $100-103$.

Maslianskaia-Pautrel M, Baumont C, 2013. Spatial weights configuration and impact of environmental externalities on housing prices. Available at SSRN: http://ssrn.com/abstract=2071199 or http://dx.doi.org/10.2139/ ssrn.2071199.

Panduro T E, Veie K L, 2013. Classification and valuation of urban green spaces: A hedonic house price valuation. Landscape and Urban Planning, 120: 119-128.

Platter R H, Campbell T J, 1978. A study of the effect of water view on site value. The Appraisal Journal, 46(1): 22-25.

Rosen S, 1974. Hedonic prices and implicit markets: Product differentiation in pure competition. Journal of Political Economy, 82(1): 34-55.

Shi Yishao, Li Muxiu, 2006. The analysis of housing price gradient and its impact factors of Shanghai city. Acta Geographica Sinica, 61(6): 604-612. (in Chinese)

Shi Yishao, Zhang Rui, 2010. Temporal spatial impact effects of large-scale parks on residential prices: Exemplified by the Huangxing Park in Shanghai. Geographical Research, 29(3): 510-520. (in Chinese)

Smersh G T, Smith M T, 2000. Accessibililty changes and urban house price appreciation: A constrained optimization approach to determining distance effects. Journal of Housing Economics, 9(3): 187-196.

Song Y, Zenou Y, 2012. Urban villages and housing values in China. Regional Science and Urban Economics, 42(3): 495-505.

Stevenson S, 2004. New empirical evidence on heteroscedasticity in hedonic housing models. Journal of Housing Economics, 13(2): 136-153.

Straszheim M, 1975. An Econometric Analysis of the Urban Housing Market. National Bureau of Economic Research. New York: Columbia University Press, 28.

Tse R, Love P, 2000. Measuring residential property values in Hong Kong. Property Management, 18(5): 366-374.

Waltert F, Schläpfer F, 2010. Landscape amenities and local development: A review of migration, regional economic and hedonic pricing studies. Ecological Economics, 70(2), 141-152.

Wang Yang, Fang Chuanglin, Xiu Chunliang et al., 2012. A new approach to measurement of regional inequality in particular directions. Chinese Geographical Science, 22(6): 705-717.

Wang Yang, Wang Deli, Wang Shaojian, 2013. Spatial differentiation patterns and impact factors of housing prices of China's cities. Scientia Geographica Sinica, 33(10): 1157-1165. (in Chinese)

Wen Haizhen, Li Xuning, Zhang Ling, 2012. Impacts of the urban landscape on the housing pricing: A case study in Hangzhou. Geographical Research, 31(10): 1806-1814. (in Chinese)

Yusuf A A, Resosudarmo B P, 2009. Does clean air matter in developing countries' megacities? A hedonic price analysis of the Jakarta housing market, Indonesia. Ecological Economics, 68(5): 1398-1407. 